Zeszyty Naukowe Szkoły Głównej Gospodarstwa Wiejskiego w Warszawie

Problemy Rolnictwa Światowego tom 18 (XXXIII), zeszyt 4, 2018: 50-59

DOI: $10.22630 /$ PRS.2018.18.4.96

Arkadiusz Zalewski $^{1}$

Instytut Ekonomiki Rolnictwa i Gospodarki Żywnościowej - Państwowy

Instytut Badawczy, Warszawa

\title{
Popyt na rolnicze usługi mechanizacyjne w krajach Unii Europejskiej
}

\section{Demand for Agricultural Mechanization Services in the European Union Countries}

\begin{abstract}
Synopsis. Korzystanie z usług mechanizacyjnych może w istotnym stopniu przyczyniać się do obniżania kosztów produkcji umożliwiając producentom rolnym bezinwestycyjne wdrożenie postępu technicznego. W artykule próbowano określić tendencje występujące w popycie na rolnicze usługi mechanizacyjne w krajach Unii Europejskiej w latach 2010-2017. Badano zmiany wartości usług w przeliczeniu na 1 ha UR oraz zmiany udziału usług mechanizacyjnych w zużyciu pośrednim. Stwierdzono, że wartość usług w przeliczeniu na 1 ha UR średnio w UE zwiększyła się. Wzrósł również udział usług $\mathrm{w}$ zużyciu pośrednim. W wyniku grupowania obiektów metodą Warda otrzymano 5 skupień krajów, które różniły się między sobą pod względem zaproponowanych cech, natomiast kraje tworzące dane skupienie charakteryzowały się zbliżonymi wartościami zmiennych. Krajami w których zaobserwowano zarówno wyraźny wzrost wartości usług mechanizacyjnych w przeliczeniu na jednostkę powierzchni jak również zdecydowane zwiększenie wartości usług w zużyciu pośrednim były: Finlandia, Niemcy, Łotwa, Rumunia oraz Estonia. Wyraźny spadek popytu na usługi mechanizacyjne wystapił natomiast w Grecji i na Litwie.
\end{abstract}

Słowa kluczowe: usługi rolnicze, usługi mechanizacyjne, popyt, Unia Europejska

\begin{abstract}
The use of mechanization services can significantly contribute to reducing production costs, enabling agricultural producers to implement technical progress without any investment. The article attempted to identify trends in demand for agricultural mechanization services in the European Union countries in 2010-2017. Changes in the value of services per 1 ha of UAA and changes in the share of mechanization services in total expenditures incurred for agricultural production were examined. It was found that the value of services per 1 ha of UAA on average in the EU increased. The share of services in intermediate consumption has also increased. As a result of grouping objects by the Ward method, 5 clusters of countries were distinguished, which differed among each other in terms of the proposed features, while the countries that created the focus were characterized by similar values of variables. The countries in which both a clear increase in the value of mechanization services per unit area was observed as well as a significant increase in the value of services in indirect consumption were: Finland, Germany, Latvia, Romania and Estonia. A clear decline in demand for mechanization services occurred in Greece and Lithuania.
\end{abstract}

Key words: agricultural services, mechanization services, demand, European Union

JEL Classification: C38, L89, Q14

\footnotetext{
${ }^{1}$ mgr inż., Zakład Badań Rynkowych IERiGŻ-PIB, ul. Świętokrzyska 20, 00-002 Warszawa, e-mail: Arkadiusz.Zalewski@ierigz.waw.pl; https://orcid.org/0000-0003-0471-9445
} 


\section{Wstęp}

Usługi stanowią ważny element gospodarki każdego kraju. Kołodziejczak (2016) podkreśla, że znaczenie sektora usług wzrasta wraz z rozwojem gospodarczym. Bożyk (2008) zauważa, że rozwój gospodarczy wpływa na rosnące znaczenie sektora usługowego w gospodarce narodowej, ale też $\mathrm{z}$ drugiej strony sektor usług przyczynia się do zwiększenia wzrostu gospodarczego. Rosnąca rola usług w nowoczesnej gospodarce przejawia się zwiększeniem ich udziału w zatrudnieniu, wytwarzaniu i konsumpcji, a społeczeństwa stają się społeczeństwami usługobiorców (Lotko, 2017). W krajach wysoko rozwiniętych sektor usług wytwarza około $2 / 3$ wartości dodanej oraz stanowi mniej więcej taki sam udział w ogólnym zatrudnieniu (Dominiak, Hauke, 2015). Jak podaje Stefaniak (2007) najwyższy odsetek zatrudnionych w sektorze usługowym występuje w Luksemburgu, Holandii, USA, Wielkiej Brytanii i Szwecji. Autorka wskazuje ponadto, że zatrudnienie w usługach wymaga bardzo różnych kwalifikacji, co przekłada się na możliwości generowania pracy dla osób o różnym poziomie wykształcenia. Stefaniak (2007) podkreśla, że usługi coraz intensywniej przenikają do przemysłu i rolnictwa, co w dużej mierze jest wynikiem rozwoju technologicznego.

Jak podaje Kołodziejczak (2013) ze względu na konieczność podnoszenia jakości procesów produkcyjnych i kwestie ekonomiczne znaczenie usług w rolnictwie staje się coraz większe. Kołodziejczak i Poczta (2014) zauważają, że korzystanie z usług przez producentów rolnych określa kondycję ekonomiczną gospodarstw, ale jest też czynnikiem, który buduje ich nowoczesność i siłę ekonomiczną. Radwan (2001) zauważa, że rolnicy którzy dążą do zwiększenia siły produkcyjnej swoich gospodarstw muszą poszukiwać sposobów racjonalizacji struktury czynników produkcji, a korzystanie z usług produkcyjnych może eliminować lub łagodzić skutki niedoborów czynnika znajdującego się w minimum. Według Pawlaka (2005) usługi mechanizacyjne umożliwiają pełniejsze zmechanizowanie prac produkcyjnych bez konieczności dodatkowych nakładów inwestycyjnych, lepsze wykorzystanie istniejących zasobów środków mechanizacji rolnictwa oraz poprawę efektywności nakładów na środki trwałe.

Według Kołodziejczak (2016) najczęstszym powodem korzystania z usług rolniczych jest brak ekonomicznego uzasadnienia dla samodzielnego wykonywania prac ze względu na większą efektywność usługi, a także brak konieczności inwestowania w kosztowne maszyny i urządzenia. Innym powodem korzystania z usług rolniczych może być również niedobór siły roboczej lub potrzeba wygospodarowania wolnego czasu przez właściciela gospodarstwa (Kołodziejczak 2015). Co więcej, jak podają Radwan i Wadoń (2011) korzystanie z usług staje się w wielu przypadkach jedyną alternatywą, zapobiegającą zaprzestaniu produkcji rolnej, zwłaszcza w gospodarstwach uzyskujących dochody z działalności pozarolniczej. Korzystanie z usług mechanizacyjnych pozwala zatem nie tylko ograniczyć inwestycje w nowy sprzęt rolniczy, ale daje również możliwość wprowadzenia do gospodarstwa nowoczesnych środków technicznych i zmian technologicznych oraz organizacyjnych. Według Radwana (2010) korzystanie z usług jest skutecznym sposobem przezwyciężania sprzeczności między konsekwencją wprowadzania postępu technicznego do rolnictwa a kosztami i możliwościami jego wdrożenia.

Radwan (2010) stwierdza, że popularną formą usług mechanizacyjnych, rozpowszechnioną w wielu krajach Unii Europejskiej, są usługi świadczone sąsiadom przez rolników dysponujących odpowiednimi środkami mechanizacji oraz nadwyżkami siły roboczej. Według Kołodziejczak (2013) zakup maszyn bardziej wydajnych niż wynika to 
z realnych potrzeb gospodarstwa przyczynia się do rozwoju usług na lokalnym rynku. Korzyści producentów rolnych świadczących usługi w ramach pomocy sąsiedzkiej polegają na obniżeniu kosztów eksploatacji maszyn, dzięki poprawie ich wykorzystania. Dzięki temu skraca się okres eksploatacji maszyn, przez co może nastąpić szybsza wymiana parku maszynowego (Kowalski i in., 1994; Szuk, 2009).

Wielu autorów wskazuje na rosnące znaczenia usług w polskim rolnictwie. Kołodziejczak (2010) zauważa, że w latach 1999-2009 wartość usług rolniczych w przeliczeniu na 1 ha UR oraz ich udział w strukturze zużycia pośredniego zwiększały się. Kołodziejczak i Poczta (2014) stwierdzają, że w latach 1998-2012 zwiększała się wartość usług rolniczych w Polsce liczona w cenach stałych, przy czym średnia roczna dynamika zmian w tym okresie było znacznie większa niż w Niemczech. Niemniej jednak Radwan (2001) uważa, że w Polsce usługi stanowią wciąż niewielki udział w nakładach produkcyjnych rolnictwa i podstawowych wielkościach produkcji rolniczej, w stosunku do tych wielkości, jakie są osiagane $\mathrm{w}$ krajach rozwiniętych gospodarczo. Według Kołodziejczak (2013) w grupie krajów Europy Środkowo-Wschodniej w latach 2007-2012 udział usług rolniczych w całości nakładów ponoszonych na produkcję rolniczą zwiększył się przede wszystkim w Estonii, na Litwie i w Czechach, zmalał natomiast głównie w Rumunii, Bułgarii i Słowenii. Z badań Kołodziejczak (2016) wynika ponadto, że w krajach UE najmniejszy udział kosztu zakupu usług w zużyciu pośrednim w 2013 r. występował w Słowenii, Polsce, Czechach, Chorwacji, na Łotwie, Litwie, ale też w Portugalii. Gospodarstwa $\mathrm{z}$ tych krajów cechowały się ponadto najmniejszym poziomem kosztu zakupu usług $\mathrm{w}$ przeliczeniu na 1 pełnozatrudnionego $\mathrm{i} 1$ ha UR. Z kolei w Holandii, Francji i Belgii wskaźniki te należały do najwyższych, w porównaniu z pozostałymi krajami UE. Autorka wskazuje ponadto, że na stopień korzystania z usług w większym stopniu niż zmienne ilościowe oddziałują zaszłości historyczne i regulacje związane z polityką UE.

Budzi zatem ciekawość jak zmieniał się popyt na usługi mechanizacyjne w krajach UE w ostatnich latach. Celem artykułu była próba zidentyfikowania i porównania tendencji w popycie na usługi mechanizacyjne dla rolnictwa w krajach UE w latach 2010-2017.

\section{Materiał i metodyka badań}

W pracy badano jak zmieniały się koszty zakupu usług mechanizacyjnych dla rolnictwa w krajach Unii Europejskiej (w cenach bieżących oraz cenach stałych z 2010 r.) w latach 2010-2017. Analizowano udział wartości usług mechanizacyjnych w zużyciu pośrednim. Pogrupowano kraje pod względem zmian wartości usług mechanizacyjnych w przeliczeniu na 1 ha UR oraz zmian udziału usług w zużyciu pośrednim w latach 20102017.

Do badań wykorzystano Rachunki Ekonomiczne dla Rolnictwa (RER) z bazy danych Eurostat. Uwzględniono pozycję „usługi rolnicze”, która obejmuje najem maszyn i wyposażenia z odpowiednią robocizną (Rozporządzenie (WE) nr 138/2004 Parlamentu Europejskiego i Rady z dnia 5 grudnia 2003 r. dotyczące rachunków gospodarczych dla rolnictwa we Wspólnocie). Inne usługi, np. weterynaryjne i pośrednictwa finansowego stanowiły odrębną kategorię, która nie była przedmiotem badań.

Do pogrupowania krajów wykorzystano analizę skupień. Polega ona na dzieleniu zbioru danych na grupy w taki sposób, aby uzyskać skupienia, w których elementy w tej 
samej grupie są do siebie podobne, a jednocześnie różne od elementów z innych grup. W artykule do pogrupowania krajów w skupienia zastosowano metodę Warda, która należy do hierarchicznych metod klasyfikacji obiektów. Metody hierarchiczne są najprostszymi i najczęściej używanymi metodami analizy skupień. Metoda Warda różni się od innych metod hierarchicznych tym, że odległości miedzy skupieniami określane są w oparciu o analizę wariancji. Zmierza ona na minimalizacji sumy kwadratów wewnątrz skupień. Istotne jest zatem to, że metoda Warda zapewnia homogeniczność wewnątrz skupień i heterogeniczność między skupieniami. Uznawana jest przez to za najbardziej efektywna. Metoda ta przedstawia najbardziej naturalne skupiska elementów (Ward, 1963; Marek, 1989; Młodak, 2006).

Zmienne opisujące zmiany wartości usług mechanizacyjnych w przeliczeniu na 1 ha UR oraz zmiany udziału usług $\mathrm{w}$ zużyciu pośrednim zostały poddane weryfikacji statystycznej ze względu na współczynnik zmienności oraz współczynnik korelacji. Wartości tych współczynników nie przekraczały wyznaczonych wartości granicznych, wiec zmienne mogły być podstawą tworzenia skupień.

$\mathrm{W}$ analizach z użyciem metody Warda istotne jest ujednolicenie poziomu zmienności cech, w celu zapewnienia ich porównywalności. Analizy przeprowadzono dla zmiennych standaryzowanych. Przy formowaniu skupień zastosowano odległość Czebyszewa. Powstała $\mathrm{w}$ ten sposób hierarchiczna struktura skupień została przedstawiona $\mathrm{w}$ formie drzewa skupień (dendrogramu). Wyniki poddano analizie porównawczej i opisowej. Do obliczeń wykorzystano program Statistica 8.0.

\section{Wartość rolniczych usług mechanizacyjnych w krajach Unii Europejskiej}

Łączna wartość zakupu usług mechanizacyjnych $\mathrm{w}$ rolnictwie $\mathrm{w}$ krajach Unii Europejskiej w cenach bieżących zwiększyła się w latach $2010-2017$ r. o $18,1 \%$ do 17,9 mld euro. Wzrost wartości usług był jednak również powiązany z rosnącymi cenami usług. Dla porównania wartość usług wyrażona $w$ cenach stałych (z 2010 r.) wzrosła w analizowanym okresie o $12,1 \%$ do 17,0 mld euro. W przeliczeniu na 1 ha UR wartość zakupu usług zwiększyła się z 86,3 euro/ha w 2010 r. do 98,1 euro/ha w 2017 r., tj. o 13,7\%. Można zatem stwierdzić, że popyt na usługi mechanizacyjne w UE w latach 20102017 zwiększył się.

W latach 2010-2017 w ramach Unii Europejskiej zdecydowanie największy wzrost zakupionych przez producentów rolnych usług mechanizacyjnych (w cenach stałych z 2010 r.) odnotowano w Finlandii (o 261,5\%), w Estonii (o 135,2\%), na Łotwie (o 81,1\%), w Rumunii (o 50,0\%) oraz w Niemczech (o 47,7\%). W Szwecji, Hiszpanii i na Słowacji wzrost wartości usług był wyraźnie mniejszy i wynosił około 20-25\%. Z kolei wyraźny spadek wartości zakupu usług mechanizacyjnych (o ponad 20\%) w analizowanym okresie odnotowano przede wszystkim na Litwie, w Grecji, Słowenii oraz Belgii. 


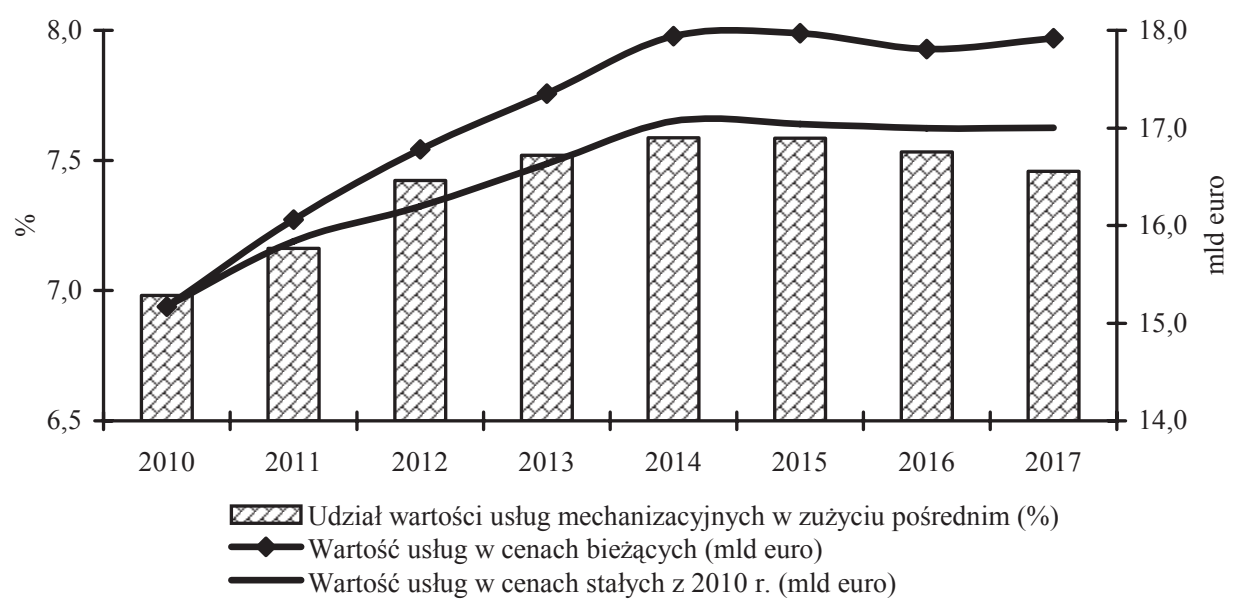

Rys. 1. Wartość usług mechanizacyjnych (prawa oś) oraz ich udział w zużyciu pośrednim (lewa oś) w UE

Fig. 1. Value of mechanization services (right axis of the chart) and their share in intermediate consumption (left axis of the chart) in the EU

Źródło: opracowanie własne na podstawie Rachunków Ekonomicznych dla Rolnictwa (RER) z bazy danych Eurostat.

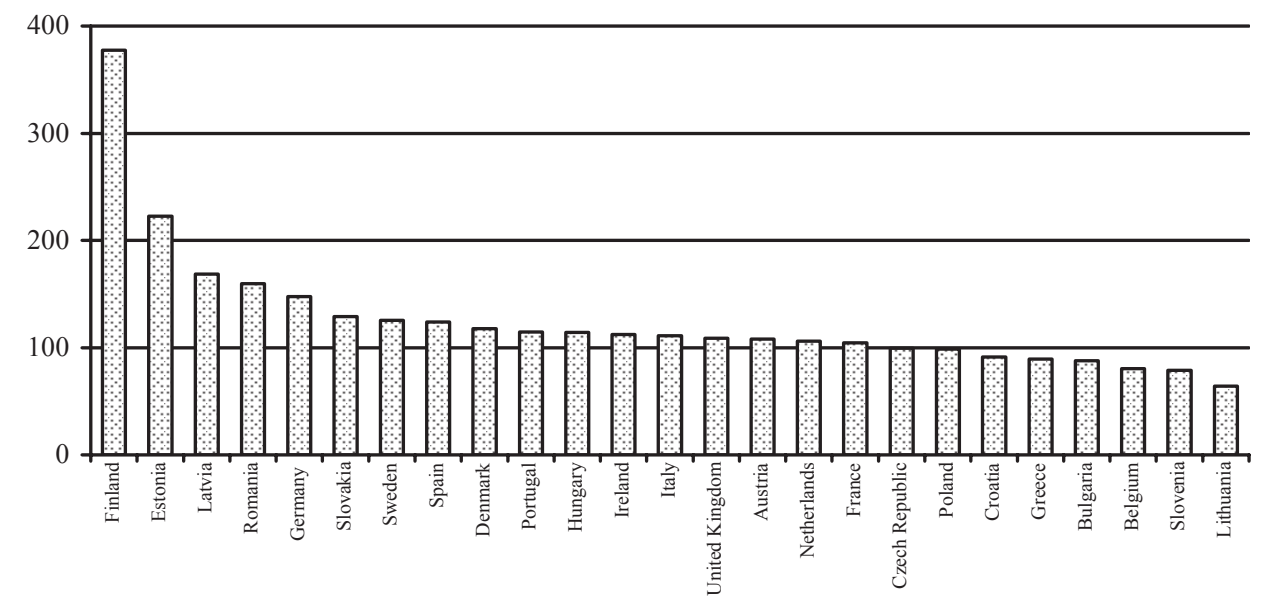

Rys. 2. Zmiany wartości usług mechanizacyjnych w przeliczeniu na 1 ha UR w cenach stałych w wybranych krajach UE w latach 2010-2017 (2010=100)

Fig. 2. Changes in the value of mechanization services per 1 ha of UAA in constant prices in selected EU countries in 2010-2017 $(2010=100)$

Źródło: opracowanie własne na podstawie Rachunków Ekonomicznych dla Rolnictwa (RER) z bazy danych Eurostat.

Zmiany wartości zakupionych przez rolników usług mechanizacyjnych w latach 20102017 w niektórych krajach w pewnym stopniu wynikały ze zmian powierzchni użytków 
rolnych. W przeliczeniu na 1 ha UR wartość zakupu usług w Finlandii wzrosła (o 277,5\%), Estonii (o 122,4\%), na Łotwie (o 68,5\%), w Rumunii (o 59,6\%) i Niemczech (o 47,6\%). Wyraźny spadek kosztów usług w przeliczeniu na jednostkę powierzchni odnotowano natomiast na Litwie (o 36,0\%), w Słowenii (o 21,2\%), Belgii (o 19,6\%) i Bułgarii (o 12,3\%). W Grecji całkowita wartość usług zmalała wprawdzie o 21,5\%, jednak wynikało to w dużym stopniu ze spadku powierzchni UR. W przeliczeniu na 1 ha UR koszty usług w tym kraju zmniejszyły się o 10,7\%.

\section{Udział usług mechanizacyjnych w zużyciu pośrednim w rolnictwie krajów UE}

Udział kosztu zakupu usług mechanizacyjnych w zużyciu pośrednim (obliczony dla cen stałych z 2010 r.) w UE w 2017 r. wyniósł średnio 7,5\% i był o 0,5 pkt. proc. większy w porównaniu z $2010 \mathrm{r}$. Oznacza to, że znaczenie usług mechanizacyjnych w zużyciu pośrednim relatywnie wzrosło. Dla porównania w analizowanych latach np. udział kosztów zakupu pasz w zużyciu pośrednim zmalał z 37,1 do $36,8 \%$, udział nośników energii pomniejszył się z 11,5 do 11,3\%, udział nawozów wzrósł o 0,5 pkt. proc. do 7,5\%, środków ochrony roślin powiększył się z 4,6 do 5,2\%, a usług weterynaryjnych zmalał o 0,2 pkt. proc do $2,7 \%$.

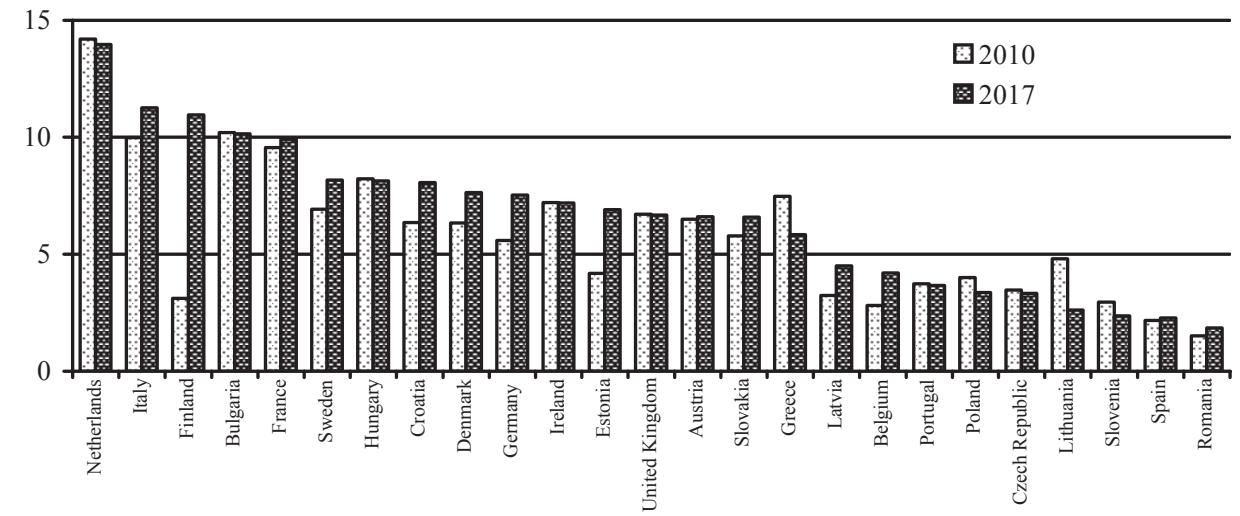

Rys. 3. Udział wartości usług mechanizacyjnych w zużyciu pośrednim w 2010 i 2017 r. w wybranych krajach UE

Fig. 3. Share of the value of mechanization services in intermediate consumption in 2010 and 2017 in selected EU countries

Źródło: opracowanie własne na podstawie Rachunków Ekonomicznych dla Rolnictwa (RER) z bazy danych Eurostat.

Udział wartości usług mechanizacyjnych w zużyciu pośrednim był wyraźnie zróżnicowany pomiędzy poszczególnymi krajami UE. W 2017 r. zdecydowanie największy udział kosztów usług w zużyciu pośrednim odnotowano w Holandii (14,0\%), Włoszech $(11,3 \%)$, Finlandii $(11,0 \%)$, ale też w Bułgarii (10,1\%). Stosunkowo wysokim udziałem usług mechanizacyjnych w zużyciu pośrednim (powyżej średniej UE) charakteryzowało się ponadto rolnictwo we Francji, Danii, Niemczech, Szwecji, ale również w Chorwacji i na Węgrzech. Najmniejszą wartość badanego wskaźnika (poniżej 3\%) odnotowano 
w Rumunii, Hiszpanii, Słowenii i na Litwie. Można zaryzykować stwierdzenie, że korzystanie $\mathrm{z}$ usług mechanizacyjnych $\mathrm{w}$ tych ostatnich krajach nie było zbyt popularną formą użytkowania sprzętu rolniczego. Należy przy tym podkreślić, że przeciętny udział usług mechanizacyjnych w zużyciu pośrednim w krajach UE-15 był w 2017 r. około 2krotnie większy w porównaniu z pozostałymi krajami UE.

Udział usług mechanizacyjnych w zużyciu pośrednim zwiększył się w analizowanym okresie o $0,5 \%$ pkt proc, przy czym wzrost ten był $\mathrm{w}$ poszczególnych krajach niejednakowy. W krajach UE-15 powiększył się on przeciętnie z 7,5\% w 2010 r. do 8,2\%. Dla porównania w krajach UE-13 zmalało on z 4,4 do 4,1\%. W ramach całej UE największy wzrost badanego wskaźnika odnotowano w Finlandii (o 7,9 pkt. proc), w Estonii (o 2,7 pkt. proc) oraz w Niemczech (o 1,9 pkt. proc.). Zupełnie odmienna sytuacja wystąiła na Litwie $\mathrm{i}$ w Grecji. W krajach tych odnotowano dość zauważalny spadek udziału usług mechanizacyjnych $\mathrm{w}$ zużyciu pośrednim, który wyniósł w analizowanym okresie odpowiednio 2,2 i 1,6 pkt. proc. Spadek ten wynikał przede wszystkim ze zmniejszenia wartości usług mechanizacyjnych.

\section{Klasyfikacja krajów UE ze względu na zmiany popytu na usługi mechanizacyjne w latach 2010-2017}

W wyniku grupowania obiektów metodą Warda otrzymano 5 skupień krajów, które różniły się między sobą pod względem zaproponowanych cech. Kraje tworzące dane skupienie charakteryzowały się natomiast zbliżonymi wartościami zmiennych. Optymalną liczbę skupień otrzymano odcinając ramiona dendrogramu tam, gdzie zaczynały się robić dłuższe, a więc tam, gdzie odległości między skupieniami robiły się istotnie większe.

W pierwszym skupieniu znalazły się kraje, takie jak Belgia, Chorwacja, Dania, Włochy, Szwecja oraz Słowacja. Są to kraje w których w latach 2010-2017 dość wyraźnie zwiększył udział wartości usług mechanizacyjnych w zużyciu pośrednim. W tej grupie krajów powiększyła się również wartość usług w przeliczeniu na 1 ha UR, jednak tempo wzrostu było stosunkowo niewielkie, mniejsze niż średnio w UE.

W drugim skupieniu znalazły się 4 kraje: Niemcy, Łotwa, Rumunia oraz Estonia. Ta grupa krajów charakteryzowała się zdecydowanym wzrostem zarówno udziału usług mechanizacyjnych $\mathrm{w}$ zużyciu pośrednim jak również wartości usług $\mathrm{w}$ przeliczeniu na jednostkę powierzchni. Można zatem stwierdzić, że popyt na usługi mechanizacyjne w tych krajach $\mathrm{w}$ analizowanych latach charakteryzował się wyraźną tendencją wzrostową.

Trzecie skupienie obejmowało kraje gdzie nastapiły stosunkowo niewielkie zmiany udziału usług mechanizacyjnych w zużyciu pośrednim jak również nieznacznie zmieniła się wartość usług w przeliczeniu na jednostkę powierzchni. W skupieniu tym znalazło się aż 12 krajów: Bułgaria, Francja, Słowenia, Czechy, Holandia, Polska, Irlandia, Węgry, Portugalia, Austria, Wielka Brytania oraz Hiszpania.

Do czwartego skupienia przyporządkowane zostały 2 kraje: Grecja oraz Litwa. W krajach tych nastapił zdecydowany spadek zarówno udziału usług mechanizacyjnych w zużyciu pośrednim jak również wartości usług w przeliczeniu na 1 ha UR. Można więc stwierdzić, że popyt na usługi mechanizacyjne w tych krajach $\mathrm{w}$ badanych latach charakteryzował się wyraźną tendencją spadkową.

Do piątego skupienia zaliczono jedynie Finlandię. W tym skupieniu tempo wzrostu udziału usług mechanizacyjnych w zużyciu pośrednim jak również wartości usług 
w przeliczeniu na 1 ha UR było zdecydowanie większe w porównaniu z pozostałymi skupieniami. Popyt na usługi mechanizacyjne w Finlandii wzrósł nieporównanie bardziej niż w innych krajach UE.

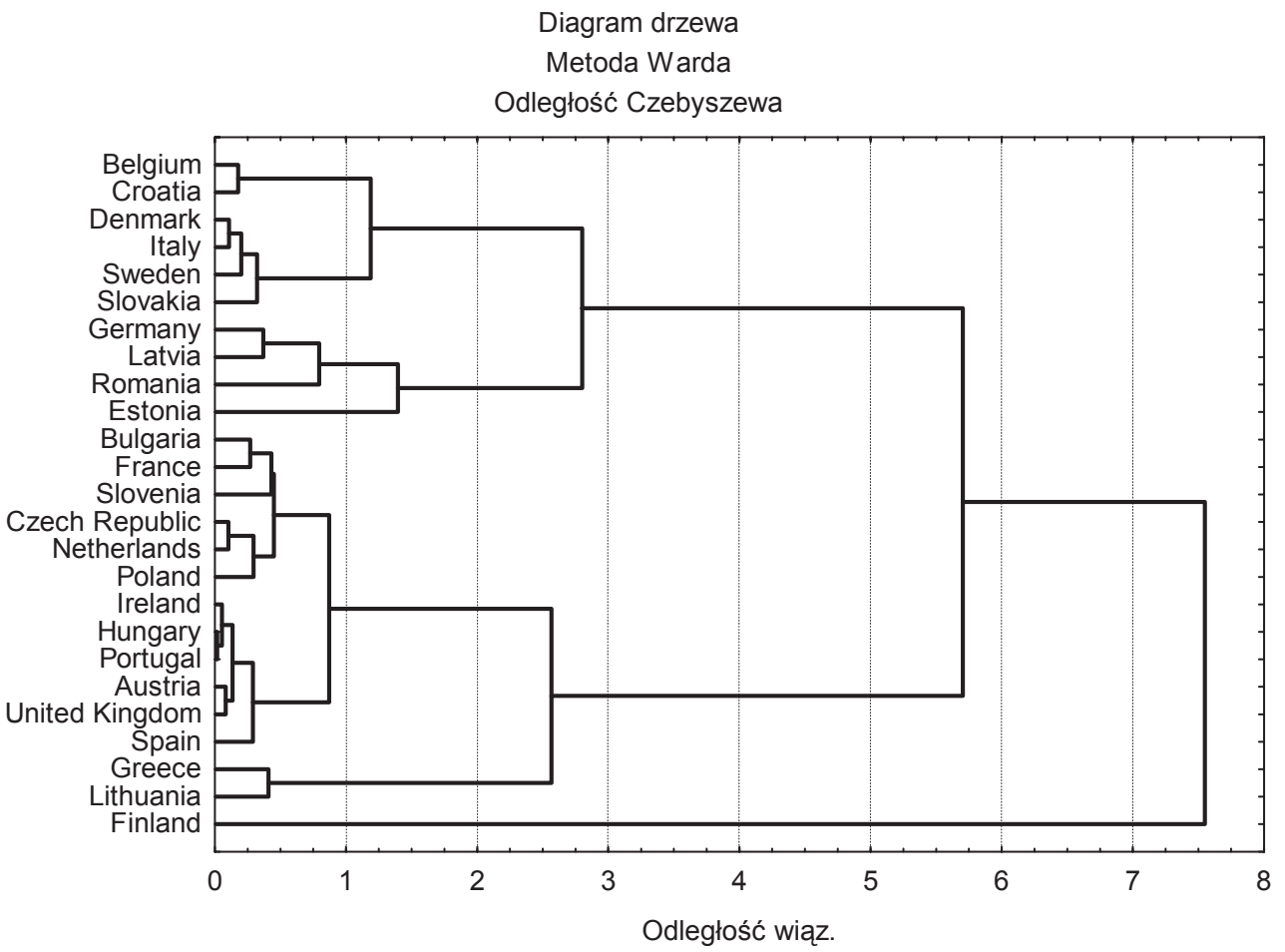

Rys. 4. Klasyfikacja krajów metodą Warda

Fig. 4. Country classification by the Ward method

Źródło: opracowanie własne na podstawie Rachunków Ekonomicznych dla Rolnictwa (RER) z bazy danych Eurostat.

Tabela 1. Średnie wartości cech w skupieniach

Table 1. Average values of variables in clusters

\begin{tabular}{|c|c|c|c|c|c|c|}
\hline \multirow{2}{*}{ Cechy } & \multicolumn{5}{|c|}{ Skupienie } & \multirow{2}{*}{$\begin{array}{l}\text { Średnio } \\
\text { dla UE }\end{array}$} \\
\hline & I & II & III & IV & V & \\
\hline $\begin{array}{l}\text { Zmiana wartości usług mechanizacyjnych } \\
\text { w przeliczeniu na } 1 \text { ha UR w latach 2010-2017 (\%) }\end{array}$ & 9,2 & 74,5 & 4,7 & $-23,4$ & 277,5 & 13,7 \\
\hline $\begin{array}{l}\text { Zmiana udziału usług w zużyciu pośrednim } \\
\text { w latach } 2010-2017 \text { (pkt. proc) }\end{array}$ & 1,3 & 1,6 & $-0,1$ & $-1,9$ & 7,9 & 0,5 \\
\hline
\end{tabular}

Źródło: opracowanie własne na podstawie Rachunków Ekonomicznych dla Rolnictwa (RER) z bazy danych Eurostat. 


\section{Podsumowanie}

Badania wykazały, że średnio w krajach UE w latach 2010-2017 nastąpił wzrost wartości usług mechanizacyjnych zarówno w cenach bieżących, jak również w cenach stałych (z 2010 r.). Zwiększyła się również wartość usług mechanizacyjnych w przeliczeniu na 1 ha użytków rolnych jak również udział usług mechanizacyjnych w zużyciu pośrednim.

W wyniku grupowania obiektów metodą Warda otrzymano 5 grup krajów, które różniły się między sobą pod względem zmian wartości usług mechanizacyjnych w przeliczeniu na jednostkę powierzchni oraz zmian udziału usług mechanizacyjnych w zużyciu pośrednim. Kraje tworzące dane skupienie charakteryzowały się z kolei zbliżonymi wartościami zmiennych. Do krajów o zdecydowanie największym wzroście popytu na usługi mechanizacyjne w latach 2010-2017 zaliczono Finlandię, Niemcy, Łotwę, Rumunię i Estonię. Spadek popytu na badane usługi zaobserwowano przede wszystkim na Litwie oraz w Grecji.

W badaniach nie analizowano przyczyn występujących zmian popytu na usługi mechanizacyjne w poszczególnych krajach. Można przypuszczać, że wyraźny wzrost popytu na usługi mechanizacyjne, który obserwowano w niektórych krajach UE, mógł być związany m.in. ze zwiększaniem efektywności produkcji, co wymagało stosowania bardziej nowoczesnych i wydajnych maszyn oraz urządzeń rolniczych przy możliwie najmniejszych nakładach. Ponadto w niektórych krajach dynamicznie zwiększyła się średnia powierzchnia gospodarstw, co wymagało zmian organizacyjnych i mogło stanowić impuls do zwiększania stopnia korzystania z usług. Zagadnienie to wymaga jednak dalszych badań.

\section{Literatura}

Bożyk, P. (2008). Międzynarodowe stosunki ekonomiczne. Teoria i polityka (International economic relations. Theory and politics). PWE, Warszawa.

Dominiak, J., Hauke, J. (2015). Sektor usług i jego zmiany w Polsce i innych krajach UE w latach 1995-2012 (The service sector and its changes in Poland and other EU countries in the period 1995-2012). Rozwój Regionalny i Polityka Regionalna, 32, 31-43.

Kołodziejczak, M. (2010). Znaczenie usług w rolnictwie polskim i niemieckim (Sense of services in the agriculture of Poland and Germany). Zeszyty Naukowe SGGW Problemy Rolnictwa Światowego, 10(2), 41-48.

Kołodziejczak, M. (2013). Korzystanie z usług w rolnictwie w krajach Unii Europejskiej z regionu Europy Środkowo-Wschodniej (Using services in agriculture in the European Union countries from Central and Eastern Europe). IX Kongres Ekonomistów Polskich, PTE, Warszawa.

Kołodziejczak, M., Poczta, W. (2014). Zmiany w poziomie i strukturze korzystania z usług w rolnictwie Polski i Niemiec w latach 1998-2012 (Changes in the Level And Structure of Utilisation of Services in Polish and German Agriculture in 1998-2012). Journal of Agribusiness and Rural Development, 1(31), 69-79.

Kołodziejczak, M. (2015). The use of services on farms in Poland (based on the FADN data). Journal of Agribusiness and Rural Development, 4(38), 725-736.

Kołodziejczak, M. (2016). Ocena korzystania z usług w gospodarstwach rolnych krajów Unii Europejskiej analiza typologiczna (Assessment of the Use of Services on Farms in the European Union Countries - a Typological Analysis). Zeszyty Naukowe SGGW Problemy Rolnictwa Światowego, 16(3), 192-198.

Kowalski, J., Cupiał, M., Tabor, S. (1994). Efektywność postępu technicznego i naukowo-technicznego w wybranych gospodarstwach chłopskich (Effectiveness of technical and scientific-technical progress in selected peasant farms). Zeszyty Problemowe Postępów Nauk Rolniczych, 415, 105-113.

Lotko, M. (2017). Wieloaspektowość definiowania usług (Different aspects of defining services). Zeszyty Naukowe Politechniki Ślaskiej, Organizacja i Zarzqdzanie, 105, 257-266.

Marek, T. (1989). Analiza skupień w badaniach empirycznych: metody SAHN (Cluster analysis in empirical research: SAHN methods). PWN, Warszawa. 
Młodak, A. (2006). Analiza taksonomiczna w statystyce regionalnej (Taxonomic analysis in regional statistics). Difin, Warszawa.

Pawlak, J. (2005). Usługi mechanizacyjne w rolnictwie polskim (Mechanization services in Polish agriculture). Problemy Inżynierii Rolniczej, 3, 23-30.

Radwan, A. (2001). Usługi produkcyjne w procesie przemian strukturalnych gospodarstw rodzinnych (Production services in the process of structural changes of family farms). Zeszyty Naukowe Akademii Rolniczej im. H. Koltataja w Krakowie. Rozprawy, 272.

Radwan, A. (2010). Usługi produkcyjne $\mathrm{w}$ gospodarstwach rodzinnych - analiza przestrzenno-czasowa (Productions services on family farms - spatial and time analysis). Infrastruktura i Ekologia Terenów Wiejskich, PAN, Kraków.

Radwan, A., Wadoń, A. (2011). Usługi rolnicze w gospodarstwach rodzinnych na terenach uprzemysłowionych (Services on family farms at industrialized areas). Roczniki Naukowe SERiA, 13(2), 382-386.

Stefaniak, J. (2007). Rola usług w gospodarce. W: Zachowania rynkowe w teorii i praktyce (The role of services in the economy. In: Market behaviors in theory and practice). Red. D. Kopycińska, Wydawnictwo Uniwersytetu Szczecińskiego, Szczecin.

Szuk, T. (2009). Usługi maszynowe w wybranych gospodarstwach rolnych Dolnego Śląska (Machine services in selected farms in Lower Silesia region). Inżynieria Rolnicza, 8(117), 199-206.

Ward, J.H. (1963). Hierarchical grouping to optimize an objective function. Journal of the American Statistical Association, 58, 236-244.

Do cytowania / For citation:

Zalewski A. (2018). Popyt na rolnicze usługi mechanizacyjne w krajach Unii Europejskiej. Problemy Rolnictwa Światowego, 18(4), 50-59; DOI: 10.22630/PRS.2018.18.4.96

Zalewski A. (2018). Demand for Agricultural Mechanization Services in the European Union Countries (in Polish). Problems of World Agriculture, 18(4), 50-59;

DOI: 10.22630/PRS.2018.18.4.96 